\title{
Fidelity Among Sirex Woodwasps and Their Fungal Symbionts
}

\author{
Ann E. Hajek • Charlotte Nielsen • Ryan M. Kepler • \\ Stefan J. Long • Louela Castrillo
}

Received: 12 December 2012 / Accepted: 11 March 2013 /Published online: 27 March 2013

(C) The Author(s) 2013. This article is published with open access at Springerlink.com

\begin{abstract}
We report that associations between mutualistic fungi and their economically and ecologically important woodwasp hosts are not always specific as was previously assumed. Woodwasps in the genus Sirex engage in obligate nutritional ectosymbioses with two species of Amylostereum, a homobasidliomycete genus of white rot fungi. In the present study, the Amylostereum species and genotypes associated with three species of Sirex native to eastern North America and one relatively recent invasive Sirex from Europe were investigated by comparing intergenic spacer regions (IGS). Sirex spp. were sampled over 6 years from 23 sites in six US states, ranging from Maine in the northeast to Louisiana in the southeast, to obtain samples of Amylostereum from mycangia of adult females. Two of the native Sirex species (Sirex nigricornis and Sirex nitidus) were associated with either Amylostereum chailletii or Amylostereum areolatum, refuting the hypothesis of strict species-specific relationships. However, the invasive Sirex noctilio and the native Sirex cyaneus were each collected with only A. areolatum or $A$. chailletii, respectively, although $S$. noctilio was associated with two different IGS genotypes of $A$. areolatum and $S$. cyaneus occurs sympatrically with the other native Sirex. In Pinus, the preferred host tree of S. nigricornis and S. noctilio, these species co-occurred in $25.9 \%$ of trees sampled, and horizontal transmission of fungal strains from $S$. noctilio to $S$.
\end{abstract}

A. E. Hajek $(\varangle) \cdot$ C. Nielsen $\cdot$ S. J. Long $\cdot$ L. Castrillo Department of Entomology, Cornell University, Ithaca, NY 14853-2601, USA

e-mail: aeh4@cornell.edu

Present Address:

R. M. Kepler

Systematic Mycology and Microbiology Laboratory, ARS, USDA, BARC-West,

Beltsville, MD 20705, USA nigricornis was documented, although only in one tree. The extent that further spread and establishment of $S$. noctilio will alter the composition of symbionts carried by native Sirex is unknown but will depend in part on the degree of flexibility in these host-symbiont associations.

\section{Introduction}

Insects using wood partner with symbionts in order to gain nutrients from a recalcitrant food source. These associations with symbionts have been thought to range from speciesspecific obligate associations [40] to partnerships with a variable community of microbes [25]. For wood-inhabiting arthropods, specific associations with symbiotic microbes have often been assumed. However, more recent studies have shown that many of these associations are instead flexible to some extent $[1,14,15]$ and that symbiont shifts have occurred due to horizontal transmission. Exposure to new symbionts, such as when exotic wood-boring insects are introduced, may increase the likelihood of symbiont shifts.

Woodwasps in the genus Sirex (Hymenoptera: Siricidae) engage in obligate nutritional ectosymbioses with white rot fungi in the genus Amylostereum (Russulales: Amylostereaceae) [40]. Amylostereum benefit from dispersal by the woodwasps; these fungi rarely make basidiocarps, reducing the likelihood that they are dispersed by the wind [35, 45]. Developing Sirex larvae bore within the wood of conifers and gain nutritive benefits either from directly eating the fungus [20] or from fungal enzymes that aid in the digestion of xylem by larval Sirex [18]. This mutualistic relationship is obligate for the hosts as presence of the fungus is required throughout the development of siricid larvae [28]. Vertical transmission of symbionts from mother to offspring 
has been assumed as the only form of transmission [43] as female woodwasps have a pair of specialized intersegmental organs (mycangia) at the base of the ovipositor in which they transport asexual arthrospores of Amylostereum to insert within trees when eggs are laid or during exploratory drilling [7]. With only vertical transmission, specificity of relations between Sirex and Amylostereum has been assumed [11, 12, 40].

Sirex woodwasps are inhabitants of naturally occurring or urban coniferous forests as well as plantations throughout the Northern Hemisphere [32], typically specializing on a single genus of host tree, although alternate host tree genera may be used [36]. Sirex species rarely cause widespread tree mortality in their native ranges, and most species only attack the transient resource of weakened or recently dead trees [9, 36]. However, in the Southern Hemisphere, the introduced European native Sirex noctilio, in association with Amylostereum areolatum, has caused serious damage to agroforestry of introduced pines (Pinus spp.), killing large numbers of overcrowded trees as well as healthy trees when S. noctilio is present at high densities [2]. During oviposition, a phytotoxic secretion is injected into the tree by $S$. noctilio females, and the secretion acts along with the fungus to impair water relations and translocation within the tree, which usually eventually results in tree death [28]. $S$. noctilio is thought to be more aggressive than other Sirex species, which is supported by comparisons of European Sirex species that show $S$. noctilio producing the greatest amount of phytotoxic secretion [38] and having the highest oviposition densities among the species examined [37].

Understanding the fungal associations of North American Sirex has taken on pressing significance with the discovery in 2005 of the introduction and establishment of S. noctilio in northeastern North America $[8,16]$. A. areolatum was subsequently reported in association with $S$. noctilio in Ontario [4] and New York state [47]. Amylostereum chailletii had previously been the only fungus believed to be associated with all North American Sirex woodwasps $[11,12,40]$, and the presence of $A$. areolatum associated with any woodwasps in North America had not been reported before S. noctilio arrived [12]. In 2009, a study principally investigating the genotypes of $A$. areolatum carried by $S$. noctilio in North America reported a novel genotype of $A$. areolatum carried by two native North American Sirex nitidus females. This demonstrated for the first time that North American Sirex could be associated with $A$. areolatum instead of $A$. chailletii [24]. We therefore conducted a study specifically focusing on the associations between Sirex species and Amylostereum species and strains and included more samples from native Sirex populations to better understand the fidelity of Sirex-Amylostereum associations. We present results describing the symbiont specificity of the three native and one invasive Sirex species in eastern North America.

\section{Methods}

\section{Collection of Amylostereum from Sirex}

Samples of the three species of Sirex native to the USA east of the Rocky Mountains were collected from 2007 to 2012 from a total of 23 sites in Georgia, Louisiana, Maine, New York, West Virginia, and Pennsylvania. In tandem, $S$. noctilio co-occurring in some of the sampling sites in New York were collected. S. noctilio has not yet expanded its distribution to Georgia, Louisiana, Maine, or West Virginia and was therefore not sampled from these states [23]. Collection data for the 194 Sirex females that were sources for the Amylostereum species and genotypes used in the present study are presented in Table 1.

Living Sirex were collected in three different ways: (1) with aerial nets near stacks of freshly cut pine trees $(6.2 \%$ of Sirex specimens), (2) from panel traps with $70 \% \alpha$-pinene and $30 \% \beta$-pinene lures (Aptiv, Portland, OR, USA) and ethanol lures placed at Sirex-infested sites (19.1\%), or (3) when emerging from Sirex-infested red or scots pine (Pinus resinosa and Pinus sylvestris, respectively), balsam fir (Abies balsamea), or Norway spruce (Picea abies) (74. $7 \%$ ); different collection methods were not used equally for different Sirex species. For the latter method, trees were felled in the spring or early summer, and portions of trees infested by Sirex were placed in screened barrels $(69-79 \mathrm{~cm}$ height $\times 24-48 \mathrm{~cm}$ diameter) under ambient conditions. Barrels were checked regularly for emergence from early July-mid-December. Native woodwasp species collected included Sirex cyaneus, which prefers fir (Abies spp.), $S$. nitidus, which prefers spruce (Picea spp.), and S. nigricornis [= Sirex edwardsii; 13], which prefers pine (Pinus spp.). These species can be sympatric in northeastern North America, although distributions are determined in part by distributions of host trees [32]. S. noctilio prefers pine and sometimes co-infests trees with $S$. nigricornis, although emergence of the relatively short-lived adult females of these two species is often separated by at least a month in northeastern North America (KJ Dodds, personal communication). Most specimens came from rearings, and all Sirex reared from wood emerged from the genus of tree preferred by that Sirex species. Sirex species were identified using the key in Schiff et al. [31], with adjustments and confirmations by Dr. H. Goulet, Canadian National Collection of Insects, and Dr. E.R. Hoebeke, Cornell University.

Fungal symbiont samples could be collected only from adult female Sirex. Living female woodwasps were killed by exposure to ethyl acetate, cadavers were swabbed with $70 \%$ ethanol and dissected, and mycangia were removed with a microcurette [41]. To establish fungal cultures, the contents of one mycangium were transferred to a Petri dish containing potato dextrose agar (PDA) amended with 
Table 1 Locations and years for collection of Sirex-infested wood from which Sirex were reared, collection of Sirex in traps, or collection of Sirex with nets

\begin{tabular}{|c|c|c|c|c|c|}
\hline Sirex species & State & County/parish & Year & $\begin{array}{l}\text { Number } \\
\text { of specimens }\end{array}$ & $\begin{array}{l}\text { S. noctilio } \\
\text { in the area }\end{array}$ \\
\hline Sirex cyaneus & New York & Essex & 2008 & 2 & No \\
\hline Sirex cyaneus & New York & Essex & 2009 & 9 & No \\
\hline Sirex cyaneus & West Virginia & Tucker & 2009 & 1 & No \\
\hline Sirex nigricornis & Georgia & Burke & 2008 & 3 & No \\
\hline Sirex nigricornis & Louisiana & Grant & 2008 & 18 & No \\
\hline Sirex nigricornis & Louisiana & Grant & 2009 & 16 & No \\
\hline Sirex nigricornis & Louisiana & Grant & 2010 & 53 & No \\
\hline Sirex nigricornis & Louisiana & Rapides & 2010 & 6 & No \\
\hline Sirex nigricornis & Maine & Penobscot & 2011 & 2 & No \\
\hline Sirex nigricornis & Maine & Penobscot & 2012 & 2 & No \\
\hline Sirex nigricornis & New York & Onondaga & 2007 & 1 & $\mathrm{Yes}^{\mathrm{b}}$ \\
\hline Sirex nigricornis & New York & Oswego & 2007 & 4 & Yes $^{\mathrm{b}}$ \\
\hline Sirex nigricornis & New York & Oswego & 2009 & 1 & Yes $^{\mathrm{b}}$ \\
\hline Sirex nigricornis & New York & Seneca & 2007 & 1 & Yes $^{\mathrm{b}}$ \\
\hline Sirex nigricornis & New York & Tompkins & 2011 & 3 & Yes $^{\mathrm{b}}$ \\
\hline Sirex nigricornis & New York & Warren & 2008 & 1 & Yes $^{\mathrm{b}}$ \\
\hline Sirex nigricornis & New York & Warren & 2010 & 22 & Yes $^{b}$ \\
\hline Sirex nigricornis & Pennsylvania & Greene & 2008 & 6 & No \\
\hline Sirex nigricornis & Pennsylvania & Tioga & 2011 & 1 & $\mathrm{Yes}^{\mathrm{b}}$ \\
\hline Sirex nitidus & Maine & Penobscot & 2011 & 2 & No \\
\hline Sirex nitidus & Maine & Waldo & 2008 & 1 & No \\
\hline Sirex nitidus & Maine & Waldo & 2012 & 3 & No \\
\hline Sirex nitidus & New York & Essex & 2008 & 8 & No \\
\hline Sirex nitidus & New York & St. Lawrence & 2008 & 1 & Yes $^{\mathrm{b}}$ \\
\hline Sirex noctilio & New York & Oswego & 2007 & 2 & Yes \\
\hline Sirex noctilio & New York & Warren & 2010 & 25 & Yes \\
\hline
\end{tabular}

Sirex specimens listed were all females used to obtain Amylostereum from mycangia

${ }^{a}$ Over the study period, the distribution of $S$. noctilio changed, increasing from four to seven states [19]. This column indicates whether S. noctilio occurred in that county at the time the sample was collected

${ }^{\mathrm{b}}$ Detected by federal or state surveys [23] or from Hajek laboratory collections

antibiotics $\left(300 \mathrm{mg} / \mathrm{L} \mathrm{SO}_{4}-\right.$ streptomycin). Cultures were grown in constant dark at $22 \pm 1{ }^{\circ} \mathrm{C}$. The second mycangia were placed in individual tubes containing buffer (UltraClean Soil DNA Isolation Kit; MO BIO Laboratories Inc., Carlsbad, CA, USA) and stored at $-20^{\circ} \mathrm{C}$ until further processing.

DNA Extraction, Amplification, and Genotyping

Fungal DNA was extracted either from cultures or from mycangia using either an UltraClean Soil DNA Kit (MO BIO Laboratories Inc., Carlsbad, CA, USA) or a GeneCleanIII Kit (MP Biomedical, Salon, OH, USA) following the manufacturer's instructions. The intergenic spacer region (IGS) between the nuclear ribosomal large subunit and 5S DNA genes was PCR-amplified with the primers P1 and 5S-2B following the protocol from Nielsen et al. [24]. Products were visualized with ethidium bromide on 1-1.5\% agarose gels [24, 35]. Amylostereum samples were identified to species level based on the lengths of IGS amplicons. All isolates identified as $A$. areolatum were verified by direct sequencing with Applied Biosystems 3730xl DNA Analyzer (Foster City, CA, USA) at the Core Laboratories Center (CLC), Cornell University, and most isolates identified as $A$. chailletii were also verified by sequencing.

The nuc-IGS-rDNA region may be present in $A$. areolatum as multiple different copies. Heterogeneity can arise either from different nuclei having different IGS sequences within a genotype or from different ribosomal repeats within individual nuclei. Heterologous $A$. areolatum isolates were evidenced by noisy sequencing trace files. These isolates were investigated further either by cloning, 
as described by Nielsen et al. [24], or with fragment analysis, which exploits size differences between copies based on indels. To generate IGS amplicons within the size range suitable for fragment analysis with an Applied Biosystems 3730xl DNA Analyzer, an internal primer that was able to amplify fragments under 500 base pairs in length was designed. By generating an alignment using the sequences found in Nielsen et al. [24], we identified a region showing $100 \%$ site conservation. The primer IGS-intF (5'GTTTCTTAGGGCTGTTCCAGACTTGTG-3') was designed from this region using the program Primer3 [27]. This includes a seven-base-pair "pigtail" (GTTTCTT) added to the $5^{\prime}$ end to limit the addition of terminal non-template nucleotides [6]. The primer 5S-2B was labeled with a FAM fluorescent marker. The accuracy of this procedure was validated by sizing amplicons generated with the primers IGS-intF and 5S-2B from North American isolates whose IGS genotypes were determined previously by cloning. PCR reactions for fragment analysis were run under the following conditions: one cycle at $94{ }^{\circ} \mathrm{C}$ for $4 \mathrm{~min}, 35$ cycles of $94{ }^{\circ} \mathrm{C}$ for $50 \mathrm{~s}, 55^{\circ} \mathrm{C}$ for $45 \mathrm{~s}, 72{ }^{\circ} \mathrm{C}$ for $45 \mathrm{~s}$, a final extension at $72{ }^{\circ} \mathrm{C}$ for $10 \mathrm{~min}$, and then holding at $4{ }^{\circ} \mathrm{C}$ until gel visualization. Samples were mixed with formamide and LIZ500 size standard and then electrophoresed with the Applied Biosystems 3730xl DNA Analyzer at CLC, and fragment sizes were determined with PeakScanner v1. 0 (Applied Biosystems Inc.) (Fig. 1).

\section{Vegetative Compatibility Group Analysis}

Vegetative compatibility group (VCG) analysis was conducted to investigate compatibility among $A$. areolatum IGS-BE cultures from Louisiana, Maine, and New York (Table 2). Thus, some of the isolates originated $>2,000 \mathrm{~km}$ from each other. As a control, each of these isolates was also tested against $A$. areolatum IGS-BD from $S$. noctilio in New York. Isolates of A. areolatum maintained on PDA were tested in pairs and assigned to different VCG groupings using the procedure of Thomsen and Koch [42] and Nielsen et al. [24]. Inoculations were made with approximately $0.7 \times 0.7-\mathrm{cm}$ square plugs cut from the edges of actively growing cultures and placed approximately $2 \mathrm{~cm}$ apart in the center of a 6-cm-diameter Petri dish containing PDA. All plates were incubated at $23 \pm 2{ }^{\circ} \mathrm{C}$ in constant darkness for 2-4 weeks. Isolates were regarded as incompatible when a brown demarcation zone without fungal growth occurred between the isolates and compatible when hyphae intermingled freely between isolates.

\section{Co-occurrence of S. noctilio and S. nigricornis in Pines}

To explore the frequency with which $S$. noctilio and $S$. nigricornis emerged from the same pine trees, pines from which all Sirex that emerged within barrels (both males and females) had been counted were included. Sirex rearings from 58 pine trees from New York and Pennsylvania were included in this analysis (Table 3). In 2007 and 2010, all Sirex were reared from adjacent sections of trees in the same barrel, and for nine of these trees both $S$. nigricornis and S. noctilio emerged, allowing quantification of co-occurrence within individual sections of trees.

\section{Results}

\section{Amylostereum Genotyping}

The nuc-IGS-rDNA regions were successfully amplified for all isolates included in this study, both for in vitro isolates as well as when fungal DNA was extracted directly from Sirex mycangia. Samples originating from the same Sirex individual always resulted in identical sequence results independently of whether DNA was isolated from cultures or mycangia. Fragment sizes were homogeneous and species specific for A. chailletii (552 bp). In contrast, IGS was in some cases present as multiple divergent copies in A. areolatum, possibly arising from balanced heterokaryosis in the fungal thallus. IGS copies differed by SNPs and indels. Fragment analysis successfully distinguished between amplicons belonging to the different IGS groups described in Slippers et al. [35] and Nielsen et al. [24] (Fig. 1) and can be more time efficient than cloning PCR products. The IGS A-type was estimated at $476 \mathrm{bp}$, the B-type at $492 \mathrm{bp}$, the C-type at $424 \mathrm{bp}$, the Dtype at $472 \mathrm{bp}$, the E-type at $452 \mathrm{bp}$, and the F-type at $443 \mathrm{bp}$. In the present study, only the $\mathrm{B}, \mathrm{D}$, and $\mathrm{E}$ types were documented in A. areolatum from North America, with sequences being identical to the sequences reported previously by Slippers et al. [35] and Nielsen et al. [24].

\section{Sirex-Amylostereum Associations}

Only one Amylostereum species or genotype was present in the individual mycangium of each Sirex female that was sampled. Overall, three $A$. areolatum genotypes, hereafter referred to as IGS-BE, IGS-D, and IGS-BD, and one $A$. chailletii genotype were documented based on IGS amplicons/sequences. Females of both the Pinus-preferring S. nigricornis and the Picea-preferring $S$. nitidus carried either A. areolatum or A. chailletii (Table 4). For females of $S$. nigricornis, A. chailletii was more commonly carried than $A$. areolatum (Fisher's exact test; $P<0.0001$ ). However, the percentage of $S$. nigricornis carrying $A$. areolatum was greater among samples from Pennsylvania and sites further north $(47.6 \%)$ compared with samples from the southern sites in Georgia and Louisiana (13.5\%) (Fisher's exact test; $P<0.0001$ ) (Fig. 2). For S. nitidus, there was no significant difference in the number of females 
Fig. 1 Fluorescence profile for three IGS genotypes of $A$. areolatum. The peaks on the far right are IGS fragments. a Peaks for B and D, $\mathbf{b}$ peaks for $\mathrm{B}$ and $\mathrm{E}, \mathbf{c}$ peak for $\mathrm{D}$ alone

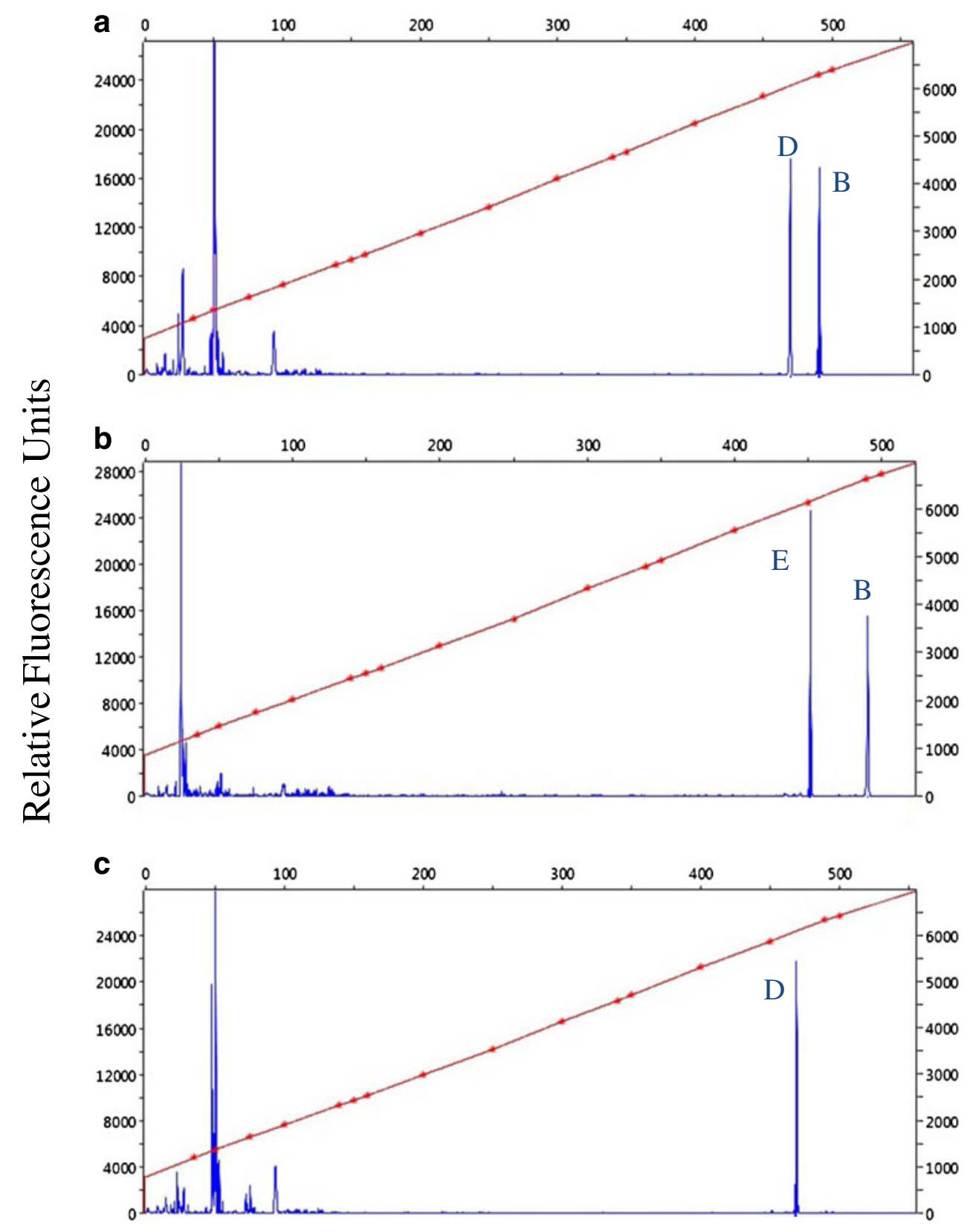

carrying A. areolatum versus $A$. chailletii (Fisher's exact test; $P=0.2429$ ). Although the number of samples of $S$. nitidus females was low $(n=15)$, individuals carrying either A. areolatum or $A$. chailletii were found both in New York and Maine states. All individuals of $S$. cyaneus carried $A$. chailletii, and $S$. noctilio always carried A. areolatum.

For Sirex that were carrying $A$. areolatum (i.e., all $S$. noctilio and some $S$. nigricornis and $S$. nitidus), either one or two IGS

Table 2 A. areolatum isolates used for vegetative compatibility tests

\begin{tabular}{llllllll}
\hline Sirex host & Isolate (SAC \#) & IGS & Collection location & County/parish & State & Collection method & Date collected \\
\hline Sirex nigricornis & 132 & BE & Warrensburg & Warren & New York & Trap & 19 Sept. 2008 \\
Sirex nigricornis & 146 & BE & Kisatchie Natl. For. & Grant & Louisiana & Insect net & 20 Nov. 2008 \\
Sirex nitidus & 81 & BE & Winterport & Waldo & Maine & Trap & 10 Sept. 2007 \\
Sirex noctilio & 101 & BD & Granby & Fulton & New York & Reared from Pinus sylvestris & 27 Dec. 2007 \\
\hline
\end{tabular}

${ }^{\text {a }}$ Sirex/Amylostereum culture collection (SAC) maintained by the Hajek laboratory at Cornell University 
Table 3 Pines from which all S. noctilio and/or S. nigricornis that emerged were counted to evaluate the extent that these Sirex species develop within the same trees and the same sections of the same trees

\begin{tabular}{lllll}
\hline $\begin{array}{l}\text { Year when trees } \\
\text { were harvested }\end{array}$ & State & Location & County & Tree species \\
\hline 2007 & NY & New Haven & Oswego & $\begin{array}{l}\text { Number } \\
\text { of trees }\end{array}$ \\
2007 & NY & Pompey & Onondaga & Pinus sylvestris \\
2008 & NY & Fingerlakes Natl. Forest & Schuyler & Pinus resinosa \\
2010 & NY & Cameron State Forest & Steuben & Pinus resinosa \\
2010 & NY & Heiberg Forest & Cortland & Pinus resinosa \\
2010 & NY & Pack Forest & Warren & Pinus resinosa \\
2010 & NY & Chaffee Road & Tompkins & Pinus resinosa \\
2011 & NY & Pompey & Onondaga & Pinus sylvestris \\
2011 & NY & Heiberg Forest & Cortland & Pinus resinosa \\
2011 & NY & Arnot Forest & Tompkins & Pinus sylvestris \\
2011 & NY & Waterburg Road & Tompkins & Pinus sylvestris \\
2011 & PA & Government Road & Tioga & Pinus resinosa \\
2011 & PA & Mountain Ridge Road & Tioga & Pinus resinosa \\
$2011^{\text {a }}$ & NY & Unknown location & Onondaga or Oswego & Pinus sylvestris \\
$2011^{\text {a }}$ & NY & Unknown location & Onondaga or Oswego & Pinus sylvestris or Pinus resinosa \\
2011 & NY & Triangle & Broome & Pinus resinosa \\
\hline
\end{tabular}

${ }^{\text {a }}$ Infested wood was obtained from USDA APHIS. Detailed records of collections were not available

amplicons were identified from each female. Whether within the distribution of $S$. noctilio or to the northeast and south, all $S$. nitidus and the vast majority of $S$. nigricornis with $A$. areolatum carried the IGS-BE genotype of $A$. areolatum (Fig. 2). This IGS type has never been documented outside the USA. The $A$. areolatum IGS-BE genotype was never found in $S$. noctilio females. $S$. noctilio females carried $A$. areolatum of the IGS-D or IGS-BD genotypes, with D being more abundant (Fisher's exact test; $P<0.0001$ ) as it was carried by $92.6 \%$ of females.

\section{VCG Compatibility}

The three $A$. areolatum IGS-BE genotypes isolated from native Sirex from different geographic locations were all incompatible with the A. areolatum IGS-BD genotype. However, the three A. areolatum IGS-BE from Louisiana, New York, and Maine were all vegetatively compatible with each other.

\section{Co-occurrence of S. noctilio and S. nigricornis in Pines}

Among the Sirex emerging from 58 pine trees, S. noctilio and S. nigricornis co-occurred in $25.9 \%$ of the trees. For the nine trees where co-occurrence within sections of trees could be determined, $98.0 \%$ of S. nigricornis emerged from sections of trees where $S$. noctilio emerged $(n=100$ total specimens) and $50.1 \%$ of $S$. noctilio emerged from sections of trees where S. nigricornis emerged ( $n=791$ total).

For four of the pines within which both $S$. noctilio and $S$. nigricornis females had developed, Amylostereum carried by adult females was determined. For three of these trees, $S$. nigricornis carried either IGS-BE A. areolatum or $A$. chailletii. However, among ten $S$. nigricornis females emerging from one $P$. sylvestris tree in New York, nine females carried $A$. chailletii and one female carried IGS-D. $S$. noctilio from the same sections of co-infested tree also carried A. areolatum IGS-D.
Table 4 Species and IGS strains of Amylostereum associated with Sirex species in eastern North America, 2007-2012

${ }^{a}$ IGS genotypes could not be determined for two additional fungal samples carried by $S$. nigricornis that were known to be $A$. areolatum

\begin{tabular}{llllll}
\hline \multirow{2}{*}{$\begin{array}{l}\text { Sirex host } \\
\text { Samples, } n\end{array}$} & A. chailletii & \multicolumn{2}{l}{ A. areolatum } & \\
\cline { 4 - 5 } & & & IGS-BE & IGS-D & IGS-BD \\
\hline Sirex nigricornis & 138 & 105 & 32 & 1 & 0 \\
Sirex cyaneus & 12 & 12 & 0 & 0 & 0 \\
Sirex nitidus & 15 & 9 & 6 & 0 & 0 \\
Sirex noctilio & 27 & 0 & 0 & 25 & 2 \\
\hline
\end{tabular}


Fig. 2 Distribution of associations of Sirex species with Amylostereum species and strains in eastern North America. Circles designating the same Sirex species that are in contact indicate fungal samples from the same collection region. Distribution of S. noctilio from [23] and the Hajek laboratory (illustration by Frances Fawcett)

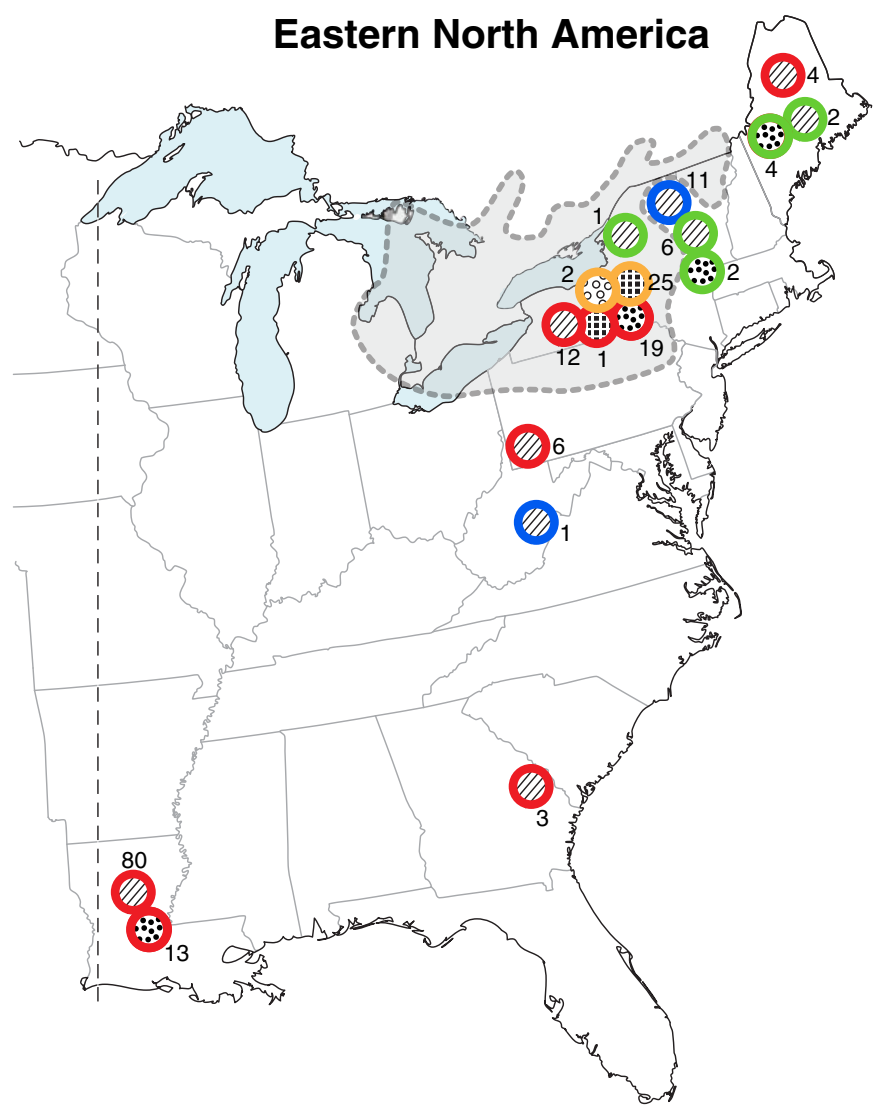

Sirex noctilio distribution

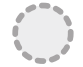

Sirex species

(2) Sirex cyaneus

- Sirex nigricornis

Sirex nitidus

Sirex noctilio

Fungus

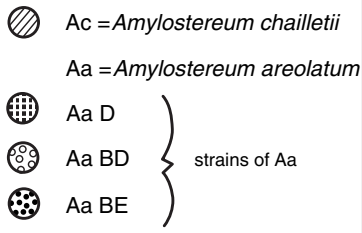

\section{Discussion}

Results from this study demonstrated that one Sirex species can be associated with more than one species or genotype of fungal symbiont. It was previously assumed that each Sirex species was associated with only one species of fungal symbiont, and in North American Sirex spp., this fungal species was always $A$. chailletii $[11,12,40]$. However, two of the three native Sirex species were found to be associated with either A. areolatum or A. chailletii (Fig. 3). In addition, associations of North American native Sirex with $A$. areolatum extended throughout the geographical range of sampled specimens, with many collections far from known $S$. noctilio infestations. In all cases, the two native Sirex species associated with $A$. areolatum carried what we believe is a North American indigenous genotype of $A$. areolatum, the IGS-BE genotype, always when outside the range of $S$. noctilio and even when within the $S$. noctilio range. Our results confirm the data of Nielsen et al. [24] which suggested that North American $S$. nitidus is sometimes associated with the IGS-BE genotype of $A$. areolatum. These findings also affirm Francke-Grosmann's predictions [10] that Sirex species could be associated with more than one species of fungal symbiont, although each Sirex species was more commonly associated with one particular fungal species. This prediction had been rejected by other authors stating that only strict species-specific associations occurred between Sirex and their fungal symbionts [e.g., 11, 12, 40].

Our data thus demonstrate that the associations between S. nigricornis or S. nitidus and Amylostereum are not strictly species or genotype specific. However, our data suggest that $S$. cyaneus could be specific to $A$. chailletii, although sample sizes for this species were low. We also found that $S$. noctilio only carried $A$. areolatum, as is known from North America [5, 24], the Southern Hemisphere [35], and Europe [2, 45]. In North America, $S$. noctilio carries two different genotypes of $A$. areolatum [5, 24]. Interestingly, in Europe, Sirex torvus (previously incorrectly known as $S$. cyaneus [13]) has been reported as being associated with either $A$. areolatum or $A$. chailletii, although association with $A$. areolatum was described as "occasional" [3]. While Gaut

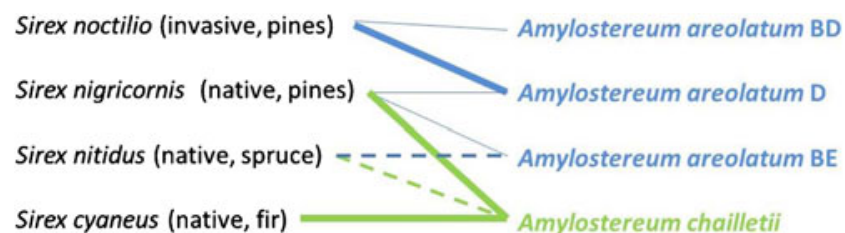

Fig. 3 Associations of Amylostereum species and strains with native and invasive Sirex species in eastern North America. Thicker lines denote more abundant associations, dashed lines denote common associations, and thinner lines denote less frequent associations 
[11] stated that $S$. torvus was only associated with $A$. areolatum, his samples came from a small geographic distribution. Thus, it seems possible that the degree of fungal specificity of Sirex species could differ by species, with some Sirex being highly specific and others less so, although more samples from more species must be examined. At present, it is still unknown whether the fitness of Sirex that develop feeding on less prevalent Amylostereum genotypes is equal to fitness when larvae feed on more prevalent symbiont genotypes. In contrast with Sirex, in the woodwasp family Xiphydriidae, five species of Xiphydria are associated with one to four species of symbiotic fungi. In this system, each Xiphydria species is associated with numerous different species and genera of hardwood trees, which influences the species of symbiotic fungi with which they are associated [26].

It has previously been assumed that the symbiotic fungi carried by Sirex species were always transferred from a Sirex female to her offspring vertically during oviposition. However, results from this study as well as previous results with $S$. nigricornis [24] suggest that at times horizontal transmission occurs. We found that $A$. areolatum IGS-D was carried by one $S$. nigricornis emerging from the same sections of a pine tree as $S$. noctilio; in a previous study, two $S$. nigricornis co-occurring in the same tree as $S$. noctilio carried A. areolatum IGS-D [24]. Studies with siricids in Europe have found identical genotypes of Amylostereum in pairs of Sirex and Urocerus species, and this has been interpreted as being suggestive of horizontal transmission [43]. In the present study, we also found that $S$. noctilio and S. nigricornis infested the same trees, and even the same sections of the same trees, fairly frequently, which would provide the proximity necessary for horizontal transmission. Co-occurrence of S. noctilio and S. nigricornis within pines in northeastern North America has also been documented in other recent studies [19, 29, 30]. Development of multiple Sirex species within the same trees creates the potential for horizontal transmission of fungal symbionts among Sirex species. We hypothesize that as $S$. noctilio becomes more established and spreads further, the potential for horizontal transmission of the A. areolatum genotypes it carries to native Sirex will increase. Curiously, in this study, $S$. noctilio females were never found carrying fungal species and genotypes assumed to be native to North America, even when they emerged from the same trees as native Sirex individuals. The phenology of this system may help to explain this. In northeastern North America, most $S$. noctilio females oviposit in July and August [49], while $S$. nigricornis oviposit in September and October (KJ Dodds, personal communication). Thus, based on phenology, the fungus carried by $S$. noctilio would often have become established within trees before $S$. nigricornis females emerged from trees and oviposited.

Our study documented two IGS genotypes, B and D, associated with $S$. noctilio in northeastern North America.
In agreement, a study by Bergeron et al. [5] documented two different multi-locus genotypes that were associated with $A$. areolatum IGS-BD or IGS-D in 2006 in Ontario, Canada. We found the $A$. areolatum IGS-BE genotype associated with $S$. nigricornis and S. nitidus in Maine and New York and with $S$. nigricornis in Louisiana. The A. areolatum IGS$\mathrm{BE}$ sequences for isolates from these distant locations were exactly the same and isolates were vegetatively compatible, suggesting that regardless of the distance between sites, these isolates are the same or very similar, although more detailed comparisons are necessary.

Studies from a variety of host-symbiont associations have reported diversity and flexibility in host/symbiont associations [e.g., 1, 14, 15, 17, 22, 33, 44]. The ability to utilize different symbionts could prevent hosts from becoming entirely aposymbiotic. It has been hypothesized that different redundant partners may confer the same type of benefit for a host, although not necessarily to the same degree. In particular, the bark beetle Dendroctonus ponderosae is associated with different fungal symbionts having different temperature tolerances under warmer versus cooler conditions, which has been hypothesized as allowing these aggressive tree-killing beetles to occupy variable habitats [34]. We hypothesize that flexibility in symbiont associations can be advantageous for Sirex. Adult females do not live very long but must locate weakened trees and oviposit during their short lives [28]. It could be advantageous for Sirex to be flexible regarding acceptability of a potential symbiont that was not carried by its mother. This change in symbiont usage could occur when females lay eggs into areas already colonized by a different Amylostereum genotype or when larvae tunnel into such areas. Also, Sirex females have been reported to sometimes eclose as adults with fungus-free mycangia [39], and in these situations, horizontal acquisition of Amylostereum would be required for subsequent Sirex larval development.

\section{Implications for Biological Control}

The fungal symbiont specificity of native Sirex has implications for the biological control of $S$. noctilio. At many locations where $S$. noctilio has been introduced in the Southern Hemisphere, a genotype of the parasitic nematode Deladenus siricidicola originating from Hungary has been effectively used as a biological control agent [2]. This nematode species has a complex life cycle with mycophagous forms that feed on A. areolatum and parasitic forms that parasitize Sirex larvae and subsequently sterilize adult females. $D$. siricidicola is very specifically associated only with $A$. areolatum $[21,48]$ but is less specific regarding which Sirex host it will parasitize as it parasitizes both $S$. noctilio and S. juvencus in Europe [3]. As $S$. noctilio populations increase and spread in North America, authorities are considering whether $D$. siricidicola 
should be introduced for classical biological control [46]. The fungal species and genotypes used by the native North American Sirex could impact whether this biological control nematode will be associated with developing Sirex larvae. Based on the present study, it seems possible that $D$. siricidicola used against $S$. noctilio could be near either $S$. nigricornis or $S$. nitidus within trees, when these Sirex are associated with $A$. areolatum. However, further studies are needed to evaluate whether the genotype of $D$. siricidicola used for biological control will successfully parasitize these non-target siricids.

\section{Conclusions}

Our studies have demonstrated that associations between Sirex and Amylostereum are not always specific. Flexibility in association of Sirex with different Amylostereum species and genotypes could provide siricids using ephemeral resources with the ability to thrive under a variety of conditions, e.g., use of weakened trees for larval development, that have already been colonized by Amylostereum. We have found that fungal symbionts of Sirex species can be swapped, but the effect of this on fitness of both exotic and native Sirex has yet to be determined. Whether the flexibility in associations of Sirex with fungal strains could have an impact on the biological control nematode associated with one fungal species remains to be determined.

Acknowledgments The authors wish to thank Bernard Slippers and Dave Williams for inspiring this work, Steve Bogdanowicz for assistance in designing the fragment analysis protocol, Wood Johnson, James Meeker, Brad Regester, Frank Drummond, James Johnson, Sandy Liebhold, Jennifer Lund, Bob Acciavatti, Eleanor Groden, and Stephen Teale for collecting specimens and infested wood, Melissa Fierke and Chris Standley for information about study sites, and Henri Goulet and E. Richard Hoebeke for Sirex identification. We thank David Williams, Tom Harrington, Michael Milgroom, Steve Rehner, Todd Ugine, Jim Liebherr, Erin Morris, and two anonymous reviewers for helpful comments. Funding was provided by USDA NIFA AFRI grant 2009-02182 and USDA APHIS.

Open Access This article is distributed under the terms of the Creative Commons Attribution License which permits any use, distribution, and reproduction in any medium, provided the original author(s) and the source are credited.

\section{References}

1. Aanen DK, Eggleton P, Rouland-Lefèvre C, Guldberg-Frøslev T, Rosendahl S, Boomsma JJ (2002) The evolution of fungusgrowing termites and their mutualistic fungal symbionts. Proc Natl Acad Sci 99:14887-14892

2. Bedding RA (2009) Controlling the pine-killing woodwasp, Sirex noctilio, with nematodes. In: Hajek AE, Glare TR, O'Callaghan M (eds) Use of microbes for control and eradication of invasive arthropods. Springer, Dordrecht, pp 213-235
3. Bedding RA, Akhurst RJ (1978) Geographical distribution and host preferences of Deladenus species (Nematoda: Neotylenchidae) parasitic in siricid woodwasps and associated hymenopterous parasitoids. Nematologica 24:286-294

4. Bergeron M-J, Hamelin RC, Leal I, Davis C, de Groot P (2008) First report of Amylostereum areolatum, the fungal symbiont of Sirex noctilio, on Pinus spp. in Canada. Pl Dis 92:1138

5. Bergeron M-J, Leal I, Foord B, Ross G, Davis C, Slippers B, de Groot P, Hamelin RC (2011) Putative origin of clonal lineages of Amylostereum areolatum, the fungal symbiont associated with Sirex noctilio, retrieved from Pinus sylvestris, in eastern Canada. Fungal Biol 115:750-758

6. Brownstein MJ, Carpten JD, Smith JR (1996) Modulation of nontemplated nucleotide addition by Taq DNA polymerase: primer modifications that facilitate genotyping. Biotechniques 20:10041006, 1008-1010

7. Coutts MP, Dolezal JE (1969) Emplacement of fungal spores by the woodwasp Sirex noctilio during oviposition. For Sci 15:412416

8. de Groot P, Nystrom K, Scarr T (2006) Discovery of Sirex noctilio (Hymenoptera: Siricidae) in Ontario, Canada. Grt Lks Entomol 39:49-53

9. Dodds KJ, de Groot P, Orwig DA (2010) The impact of Sirex noctilio in Pinus resinosa and Pinus sylvestris stands in New York and Ontario. Can J For Res 40:212-223

10. Francke-Grosmann H (1939) Über das Zusammenleben von Holzwespen (Siricinae) mit Pilzen. Z Angew Entomol 25:647-680

11. Gaut IPC (1970) Studies of siricids and their fungal symbionts. $\mathrm{Ph}$.D. thesis, University of Adelaide, Adelaide

12. Gilbertson RL (1984) Relationships between insects and woodrotting basidiomycetes. In: Wheeler Q, Blackwell M (eds) Fungusinsect relationships: perspectives in ecology and evolution. Columbia University Press, New York, pp 130-165

13. Goulet H (2012) Sirex systematics: problems and solutions. In: Slippers B, de Groot P, Wingfield MJ (eds) The Sirex woodwasp and its fungal symbiont: research and management of a worldwide invasive pest. Springer, New York, pp 1-14

14. Harrington TC, Aghayeva DN, Fraedrich SW (2010) New combinations in Raffaelea, Ambrosiella, andHyalorhinocladiella, and four new species from the redbay ambrosia beetle, Xyleborus glabratus. Mycotaxon 111:337-361

15. Harrington TC (2005) Ecology and evolution of mycophagous bark beetles and their fungal partners. In: Vega FE, Blackwell $M$ (eds) Ecological and evolutionary advances in insect-fungal associations. Oxford University Press, New York, pp 257 291

16. Hoebeke ER, Haugen DA, Haack RA (2005) Sirex noctilio: discovery of a Palearctic siricid woodwasp in New York. Newsl Mich Entomol Soc 50:24-25

17. Koga R, Tsuchida T, Fukatsu T (2003) Changing partners in an obligate symbiosis: a facultative endosymbiont can compensate for loss of the essential endosymbiont Buchnera in an aphid. Proc R Soc Lond B 270:2543-2550

18. Kukor JJ, Martin MM (1983) Acquisition of digestive enzymes by siricid woodwasps from their fungal symbiont. Science 220:11611163

19. Long SJ, Williams DW, Hajek AE (2009) Sirex species (Hymenoptera: Siricidae) and their parasitoids in Pinus sylvestris in eastern North America. Can Entomol 141:153-157

20. Madden JL, Coutts MP (1979) The role of fungi in the biology and ecology of wood wasps (Hymenoptera: Siricidae). In: Batra LF (ed) Insect-fungus symbiosis: nutrition, mutualism, and commensalism. Allanheld, Osmun

21. Morris EE, Jimenez A, Long SJ, Williams DW, Hajek AE (2012) Variability in growth of Deladenus siricidicola on strains of the white rot fungus Amylostereum areolatum. BioControl 57:677-686 
22. Mueller UG (2012) Symbiont recruitment versus ant-symbiont coevolution in the attine ant-microbe symbiosis. Curr Opin Microbiol 15:269-277

23. National Agricultural Pest Information System (NAPIS) Purdue University (2012) Survey status of Sirex woodwasp-Sirex noctilio (2009 to present). http://pest.ceris.purdue.edu/map.php? code $=$ ISBBADA\&year=3year. [Accessed 07/23/2012]

24. Nielsen C, Williams DW, Hajek AE (2009) Putative source of the invasive Sirex noctilio fungal symbiont, Amylostereum areolatum, in the eastern United States and its association with native siricid woodwasps. Mycol Res 113:1242-1253

25. Ohkuma K (2008) Symbioses of flagellates and prokaryotes in the gut of lower termites. Tr Microbiol 26:345-352

26. Pažoutová S, Šrůtka P, Holuša J, Chudíčková M, Kolařík M (2010) Diversity of xylariaceous symbionts in Xiphydria woodwasps: role of vector and a host tree. Fungal Ecol 3:392-401

27. Rozen S, Skaletsky H (2000) Primer3 on the WWW for general users and for biologist programmers. In: Krawetz S, Misener S (eds) Bioinformatics methods and protocols: methods in molecular biology. Humana, New Jersey, pp 365-386

28. Ryan K, Hurley BP (2012) Life history and biology of Sirex noctilio. In: Slippers B, de Groot P, Wingfield MJ (eds) The Sirex woodwasp and its fungal symbiont: research and management of a worldwide invasive pest. Springer, New York, pp 15-30

29. Ryan K, de Groot P, Smith SM (2012) Evidence of interaction between Sirex noctilio and other species inhabiting the bole of Pinus. Agric For Entomol 14:187-195

30. Ryan K, de Groot P, Nott RW, Drabble S, Ochoa I, Davis C, Smith SM, Turgeon JJ (2012) Natural enemies associated with Sirex noctilio (Hymenoptera: Siricidae) and S. nigricornis in Ontario, Canada. Environ Entomol 41:289-297

31. Schiff NM (2006) Guide to the siricid woodwasps of North America. USDA Forest Service FHTET-2006-15, 102 pp

32. Schiff NM, Goulet H, Smith DR, Boudreault C, Wilson AD, Scheffler BE (2012) Siricidae (Hymenoptera: Symphyta: Siricoidea) of the Western Hemisphere. Can J Arthro Ident 21: 305 pp. http://www.biology.ualberta.ca/bsc/ejournal/sgsbws 21/ sgsbws_21.html. [Accessed 10 September 2012]

33. Silverstein RN, Correa AMS, Baker AC (2012) Specificity is rarely absolute in coral-algal symbiosis: implications for coral response to climate change. Proc Roy Soc B 279:2609-2618

34. Six DL, Bentz BJ (2007) Temperature determines symbiont abundance in a multipartite bark beetle fungus ectosymbiosis. Microb Ecol 54:112-118

35. Slippers B, Wingfield BD, Coutinho TA, Wingfield MJ (2002) DNA sequence and RFLP data reflect geographical spread and relationships of Amylostereum areolatum and its insect vectors. Molec Ecol 11:1845-1854

36. Smith DR, Schiff NM (2002) A review of the siricid woodwasps and their ibaliid parasitoids (Hymenoptera: Siricidae, Ibaliidae) in the eastern United States, with emphasis on the mid-Atlantic Region. Proc Entomol Soc Wash 104:174-194

37. Spradbery JP (1973) A comparative study of the phytotoxic effects of siricid woodwasps on conifers. Ann Appl Biol 75:309-320

38. Spradbery JP (1977) The oviposition biology of siricid woodwasps in Europe. Ecol Entomol 2:225-230

39. Stillwell MA (1966) Woodwasps (Siricidae) in conifers and the associated fungus Stereum chailletii in eastern Canada. Forest Sci $12: 121-128$

40. Talbot PHB (1977) The Sirex-Amylostereum-Pinus association. Annu Rev Phytopathol 15:41-54

41. Thomsen IM, Harding S (2011) Fungal symbionts of siricid woodwasps: isolation techniques and identification. Forest Pathol $41: 325-333$

42. Thomsen IM, Koch J (1999) Somatic compatibility in Amylostereum areolatum and $A$. chailletii as a consequence of symbiosis with siricid woodwasps. Mycol Res 103:817-823

43. van der Nest MA, Wingfield BD, Wingfield MJ, Stenlid J, Vasaitis R, Slippers B (2012) Genetics of Amylostereum species associated with Siricidae woodwasps. In: Slippers B, de Groot P, Wingfield MJ (eds) The Sirex woodwasp and its fungal symbiont: research and management of a worldwide invasive pest. Springer, New York, pp 81-94

44. Verna C, Ramette A, Wiklund H, Dahlgren TG, Glover AG, Gaill F, Dubiller N (2010) High symbiont diversity in the bone-eating worm Osedax mucofloris from shallow whale-falls in the North Atlantic. Environ Microbiol 12:2355-2370

45. Wermelinger B, Thomsen IM (2012) The woodwasp Sirex noctilio and its associated fungus Amylostereum areolatum in Europe. In: Slippers B, de Groot P, Wingfield MJ (eds) The Sirex woodwasp and its fungal symbiont: research and management of a worldwide invasive pest. Springer, New York, pp 65-80

46. Williams DW, Zylstra KE, Mastro V (2012) Ecological considerations in using Deladenus (=Beddingia) siricidicola for the biological control of Sirex noctilio in North America. In: Slippers B, de Groot P, Wingfield MJ (eds) The Sirex woodwasp and its fungal symbiont: research and management of a worldwide invasive pest. Springer, New York, pp 135-148

47. Wilson AD, Schiff NM, Haugen DA, Hoebeke ER (2009) First report of Amylostereum areolatum in pines in the United States. Pl Dis 93:108

48. Yu Q, de Groot P, Leal I, Davis C, Ye W, Foord B (2009) Characterization of Deladenus siricidicola (Tylenchida: Neotylenchidae) associated with Sirex noctilio (Hymenoptera, Siricidae) in Canada. Internatl J Nematol 19:23-32

49. Zylstra KE, Dodds KJ, Francese JA, Mastro V (2010) Sirex noctilio in North America: the effect of stem-injection timing on the attractiveness and suitability of trap trees. Agric For Entomol $12: 243-25$ 